\title{
The protective effect of Nigella sativa oil in the brain of the biliary obstructed rats
}

\author{
Hale Zerrin Tokluํㅜ, Tülay Akmandor İnac ${ }^{1}$, Ahmet Özer Şehirli1, Göksel Şener ${ }^{1}$
}

ABSTRACT: Oxidative stress is one of the important mechanisms of jaundice induced encephalopathy. The aim of this study was to examine the possible protective effect of Nigella sativa (NS) seed oil against the oxidative stress of brain tissue induced by experimental obstructive jaundice in rats.

BiliarY obstruction was performed in male Wistar albino rats by bile duct ligation and scission (BDL). Intragastric NS oil (1 $\mathrm{mg} / \mathbf{k g ~ p . o . ) ~ o r ~ s a l i n e ~ w a s ~ a d m i n i s t e r e d ~ f o r ~} 28$ days. At the end of the experiment, in the half of the rats the blood brain barrier (BBB) permeability was evaluated by Evans blue (EB) extravasation. Other rats were decapitated and brain tissue samples were obtained for the measurement of malondialdehyde (MDA) and glutathione (GSH) levels, myeloperoxidase (MPO) and $\mathrm{Na}^{+}, \mathrm{K}+-\mathrm{ATPase}$ activities.

ChronIC biliary obstruction caused a significant increase in the BBB permeability which was verified by $E B$ extravasation while this effect was attenuated by NS oil treatment. On the other hand, BDL-induced decrease in brain $\mathrm{GSH}$ level and $\mathrm{Na}^{+}, \mathrm{K}^{+}-\mathrm{ATPase}$ activity were elevated back to control level in NS oil-treated BDL group. Increase in tissue MDA level, and MPO activity due to BDL were also attenuated by NS oil treatment.

Our results suggest that NS oil treatment protects the brain from oxidative damage following bile duct ligation in rats. This effect possibly involves the inhibition of neutrophil infiltration and lipid peroxidation and the restoration of antioxidant status in the tissue. Accordingly, supplementing cirrhotic patients with adjuvant therapy of NS oil may have some benefit against hepatic encephalopathy.

KEYWORDS: Nigella, black cumin, bile duct, brain, edema

\section{INTRODUCTION}

Obstruction of the common bile duct induces a reproducible model of biliary cirrhosis in rats. Hepatic fibrosis, the main complication of chronic liver disease, is usually initiated by hepatocyte damage, leading to recruitment of inflammatory cells and platelets, activation of Kuppfer cells and subsequent release of cytokines and growth factors (1). It is known that increased concentration of bile acids induce lipid peroxides, probably related to the stimulation of phagocytic activ- ity in the polymorphonuclear leukocytes and inflammatory cells, which are present after biliary tract obstruction and enhance the tissue injury $(2,3)$. Several clinical and experimental studies have shown that oxygen free radicals have a role in the pathogenesis of tissue injury in obstructive jaundice (4-7). Thus free radical ablation for the treatment of cholestatic liver injury has been shown to have beneficial effects in the prevention of fibrosis and oxidative damage following biliary obstruction.
AFFILIATIONS

1Marmara University, School of Pharmacy Department of Pharmacology, Istanbul, Türkiye

CORRESPONDENCE

Hale Zerrin Toklu

E-mail:

haletoklu@yahoo.com

Received:

07.11.2012

Revision:

07.12.2012

Accepted:

18.12.2.012 
In contrast to portacaval anastomosis, bile duct-ligated (BDL) animals have liver failure, developing jaundice, portal hypertension (8), portal-systemic shunting (9), bacterial translocation and immune system dysfunction (10). BDL rats provides a model of acute-on-chronic hepatic encephalopathy, which reproduces the human neuropathology (Alzheimer Type II astrocytosis) and alterations of brain osmolytes that are characteristic of human Type $C$ hepatic encephalopathy as well as low-grade brain oedema, inflammation and deficits of motor coordination $(11,12)$. Oxidative stress is one of the important mechanisms of jaundice induced encephalopathy.

Nigella sativa L. (N. sativa) have been widely studied due to its strong traditional claims and beliefs of having therapeutic role in almost every disease process (13-16). Several therapeutic roles have been asserted thereafter such as antioxidant, anti-inflammatory (17), analgesic, antitumor, antihistaminic (18), oral hypoglycemic (19), hepatoprotective $(20,21)$, nephroprotective (22), neuroprotective (23) and gastroprotective actions (24).

The aim of this study was to examine the possible protective effect of Nigella sativa (NS) oil against the oxidative stress of the brain tissue due to experimental obstructive jaundice in rats.

\section{METHODS}

Biliary obstruction was performed in male Wistar albino rats by bile duct ligation and scission (BDL). Intragastric NS oil or saline was administered to the BDL rats for 28 days. At the end of the experiment, in the half of the rats the blood brain barrier (BBB) permeability was evaluated by Evans blue (EB) extravasation. Other rats were decapitated and brain tissue samples were obtained for the measurement of malondialdehyde (MDA) and glutathione (GSH) levels, myeloperoxidase (MPO) and $\mathrm{Na}^{+}, \mathrm{K}^{+}$-ATPase activities.

\section{Animal model of liver fibrosis and treatment procedure}

Male Wistar albino rats (250-300 g) were housed in a room at a mean constant temperature of $22 \pm 2{ }^{\circ} \mathrm{C}$ with a 12 hour lightdark cycle, and free access to standard pellet chow and water. The study was was conducted according to the ethical guidelines of Marmara University Animal Care and Use Committee.

Liver fibrosis was induced by biliary obstruction in rats. Rats were anaesthetized $(75 \mathrm{mg} / \mathrm{kg}$ ketamine and $1 \mathrm{mg} / \mathrm{kg}$ chlorpromazine; i.p.) and the common bile duct was exposed and ligated by double ligatures with silk suture. The first ligature was made below the junction of the hepatic ducts and the second ligature was made above the entrance of the pancreatic ducts. Finally, the common bile duct was resected between the double ligatures (25). In sham-operated control rats, an incision was made in the abdomen which was then closed and given saline only. Each group consists of 12 rats (6 for biochemical studies, 6 for evaluation of edema and permeability). Nigella sativa oil (1 mg/ kg p.o.) or saline was administered for 28 days. After 28 days of treatment, rats were killed by decapitation and trunk blood was collected for the biochemical analysis in the serum. Brain tissues were stored at $-70{ }^{\circ} \mathrm{C}$ for the measurement of malondialdehyde (MDA) and glutathione (GSH) levels, myeloperoxidase (MPO) activity, $\mathrm{Na}^{+}, \mathrm{K}^{+}-\mathrm{AT}-$ Pase activity, water content and Evans blue extravasation .

\section{Biochemical analysis in the serum}

Serum AST, ALT and LDH levels (26) were determined spectrophotometrically using an automated analyzer. Serum total bilirubin level was assayed on Bayer Opera Autoanalyzer.

\section{Cytokine determination}

Serum TNF-alpha was quantified according to the manufacturer's instructions and guidelines using enzyme-linked immunosorbent assay (ELISA) kits specific for the previously mentioned rat cytokines (Biosource International, Nivelles, Belgium). These particular assay kits were selected because of their high degree of sensitivity, specificity, inter- and intra assay precision, and small amount of serum sample required to conduct the assay.

\section{Biochemical analysis in the brain tissue Malondialdehyde (MDA) and Glutathione (GSH) assays}

Tissue samples were homogenized with ice-cold trichloracetic acid ( $1 \mathrm{~g}$ tissue plus $10 \mathrm{ml}$ 10\% TCA) in an Ultra Turrax tissue homogenizer. The MDA levels were assayed for products of lipid peroxidation by monitoring thiobarbituric acid reactive substance formation as described previously (27). Lipid peroxidation is expressed in terms of MDA equivalents using an extinction coefficient of $1.56 \times 10^{5} \mathrm{M}^{-1} \mathrm{~cm}^{-1}$ and the results are expressed as nmol MDA/g tissue. Glutathione measurements were performed using a modification of the Ellman procedure (28). Briefly, after centrifugation at 2,000 $\mathrm{g}$ for $10 \mathrm{~min}, 0.5 \mathrm{ml}$ of supernatant was added to $2 \mathrm{ml}$ of $0.3 \mathrm{~mol} / 1 \mathrm{Na}_{2} \mathrm{HPO}_{4} \cdot 2 \mathrm{H}_{2} \mathrm{O}$ solution. A $0.2 \mathrm{ml}$ solution of dithiobisnitrobenzoate $(0.4 \mathrm{mg} /$ $\mathrm{ml} \mathrm{1 \%}$ sodium citrate) was added and the absorbance at 412 $\mathrm{nm}$ was measured immediately after mixing. Glutathione levels were calculated using an extinction coefficient of $1.36 \times 10^{4}$ $\mathrm{M}^{-1} \mathrm{~cm}^{-1}$. The results are expressed in $\mu \mathrm{mol} \mathrm{GSH} / \mathrm{g}$ tissue.

\section{Measurement of brain myeloperoxidase (MPO) activity}

Tissue samples were homogenized in $50 \mathrm{mM}$ potassium phosphate buffer (PB, pH 6.0), and centrifuged at 41,400 g (10 min); pellets were suspended in $50 \mathrm{mM}$ PB containing $0.5 \%$ hexadecyltrimethylammonium bromide (HETAB). After three freeze and thaw cycles, with sonication between cycles, the samples were centrifuged at $41,400 \mathrm{~g}$ for $10 \mathrm{~min}$. Aliquots $(0.3 \mathrm{ml})$ were added to $2.3 \mathrm{ml}$ of reaction mixture containing $50 \mathrm{mM} \mathrm{PB}$, o-dianisidine, and $20 \mathrm{mM} \mathrm{H} 2 \mathrm{O} 2$ solution. One unit of enzyme activity was defined as the amount of MPO present that caused a change in absorbance measured at $460 \mathrm{~nm}$ for $3 \mathrm{~min}$. MPO activity was expressed as $\mathrm{U} / \mathrm{g}$ tissue (29).

\section{$\mathrm{Na}^{+}, \mathrm{K}^{+}-$ATPase activity}

Since the activity of $\mathrm{Na}^{+}, \mathrm{K}^{+}$-ATPase, a membrane-bound enzyme required for cellular transport, is very sensitive to free radical reactions and lipid peroxidation, reductions in this activity can indicate membrane damage indirectly. Measurement of $\mathrm{Na}^{+}, \mathrm{K}^{+}$-ATPase activity is based on the measurement of inorganic phosphate released by ATP hydrolysis during incubation of homogenates with an appropriate medium containing $3 \mathrm{mM}$ ATP as a substrate. The total ATPase activity was determined in the presence of $100 \mathrm{mM} \mathrm{NaCl}, 5 \mathrm{mM} \mathrm{KCl}, 6$ $\mathrm{mM} \mathrm{MgCl}_{2}, 0.1 \mathrm{mM}$ EDTA, $30 \mathrm{mM}$ Tris $\mathrm{HCl}$ (pH 7.4), while the $\mathrm{Mg}^{2+}$-ATPase activity was determined in the presence of $1 \mathrm{mM}$ ouabain. The difference between the total and the $\mathrm{Mg}^{2+}-\mathrm{AT}$ Pase activities was taken as a measure of the $\mathrm{Na}^{+}, \mathrm{K}^{+}$-ATPase activity (30). The reaction was initiated with the addition of the homogenate $(0.1 \mathrm{ml})$ and a 5 -min preincubation period at $37^{\circ} \mathrm{C}$ 
TABLE 1. Serum total biluribin levels, aspartate aminotransferase (AST), alanine aminotransferase (ALT), lactate dehydrogenase (LDH) activities and TNF-alpha levels in control and saline- or Nigella sativa oil (NS)-treated bile duct ligated (BDL) groups.

\begin{tabular}{|c|c|c|c|}
\hline Groups & Control & BDL & $\mathrm{BDL}+\mathrm{NS}$ \\
\hline $\mathrm{LDH}(\mathrm{U} / \mathrm{L})$ & $1752 \pm 138$ & $4839 \pm 290$ *** & $2823 \pm 389+++$ \\
\hline Total Bilirubin (mg/dL) & $0.63 \pm 0.11$ & $7.18 \pm 0.62$ *** & $2.75 \pm 0.61 *,+++$ \\
\hline AST (mg/dL) & $243 \pm 12$ & $564 \pm 50 * * \star$ & $323 \pm 32+++$ \\
\hline ALT (mg/dL) & $78.3 \pm 8.7$ & $315.3 \pm 25.3^{* * *}$ & $175.3 \pm 28.9++$ \\
\hline TNF-alpha (pg/ml) & $6 \pm 0.96$ & $46.95 \pm 9.21 * \star \star *$ & $19.77 \pm 2.58++$ \\
\hline
\end{tabular}

was allowed. Following the addition of $\mathrm{Na}_{2} \mathrm{ATP}$ and a $10-\mathrm{min}$ re-incubation period, the reaction was terminated by the addition of ice-cold $6 \%$ perchloric acid. The mixture was then centrifuged at $3500 \mathrm{~g}$, and Pi in the supernatant fraction was determined by the method of Fiske and Subarrow (31). The specific activity of the enzyme was expressed as nmol $\mathrm{Pi} \mathrm{mg}^{-1}$ protein $\mathrm{h}^{-1}$. The protein concentration of the supernatant was measured by the Lowry method (32).

\section{Neurological examination}

The neurological examination scores were conducted according to Bederson's modified neurological examination test (33). A twenty-point neuroscore was used to assess motor and behavioral deficits. Briefly, the consciousness, performance in a smooth climbing platform, extremity tonus, walking and postural reflexes, circling and response to the nociceptive stimuli were assessed. For walking and posture, rats were allowed to move about freely on the floor, while they were observed. In the circling test, the rats were held gently from the tail, suspended one meter above the floor, and observed for forelimb flexion, where normal rats are expected to extend both forelimbs toward the floor. The rotation degree and time were measured. Finally, the responses to the nociceptive stimuli were assessed by tail-immersion test in $56^{\circ} \mathrm{C}$ water. All behavioral tests were conducted by a 'blinded' investigator. The sequence of testing animals by a given task was randomized for the animals.

\section{Evans blue assay for the evaluation of blood brain barrier permeability}

To evaluate the blood brain barrier (BBB) integrity, Evans blue dye (EB) was used as a marker of albumin extravasation (33). Briefly, EB (2\% in saline, $4 \mathrm{ml} / \mathrm{kg}$ ) was injected via the jugular vein at the $48^{\text {th }} \mathrm{h}$ of the SAH induction and it was allowed to remain in circulation for $30 \mathrm{~min}$. Then, chests were opened and the rats were perfused transcardially with $250 \mathrm{ml}$ of saline at a pressure of $110 \mathrm{~mm} \mathrm{Hg}$ for approximately $15 \mathrm{~min}$. After decapitation, the brain was removed and dissected into cerebral cortex and cerebellum, which were then weighed separately for the quantitative measurement of EB-albumin extravasation. Brain samples were homogenized in $2.5 \mathrm{ml}$ phosphatebuffered saline and mixed by vortexing for $2 \mathrm{~min}$ after the addition of $2.5 \mathrm{ml}$ of $60 \%$ trichloroacetic acid to precipitate the protein. Samples were cooled and then centrifuged for $30 \mathrm{~min}$ at $1000 \mathrm{~g}$. The supernatant was measured at $620 \mathrm{~nm}$ for the absorbance of EB using a spectrophotometer (Shimadzu UV1208, Japan). EB was expressed as $\mu \mathrm{g} / \mathrm{mg}$ of brain tissue against a standard curve.

\section{Evaluation of the brain edema}

Brain edema was evaluated by the gravimetric method based on the measurement of the water content of brain (33). The whole brain was weighed and then dried for $48 \mathrm{~h}$ at $100{ }^{\circ} \mathrm{C}$, afterwards re-weighed. The percentage of water was calculated according to the following formula: $\% \mathrm{H}_{2} \mathrm{O}=[$ (wet weight - dry weight) / wet weight] $\times 100$.

\section{Statistical analysis}

Statistical analysis was carried out using GraphPad Prism 3.0 (GraphPad Software, San Diego; CA; USA). All data were expressed as means \pm S.E.M. Groups of data were compared with an analysis of variance (ANOVA) followed by Tukey's multiple comparison tests. Values of $P<0.05$ were regarded as significant.

\section{RESULTS}

As shown in Table 1, serum LDH activity, total bilirubin, AST, ALT, and the plasma levels of pro-inflammatory cytokine $($ TNF- $\alpha)$ in the BDL group were significantly higher $(p<0.001)$ than that of the control group, while treatment of NS abolished these elevations significantly $(p<0.01-0.001)$.

The MDA levels, measured as a major degradation product of lipid peroxidation in the brain tissue, were found to be significantly higher in the BDL group $(\mathrm{p}<0.001)$ as compared to those of the control group, while treatment with NS abolished these elevations ( $p<0.05$; Figure 1). In accordance with these findings, levels of the major cellular antioxidant GSH in the BDL group was depleted $(\mathrm{p}<0.05)$; however, in the NS-treated BDL group, depleted GSH stores were partially replenished with this antioxidant $(\mathrm{p}<0.01$; Figure 1$)$.

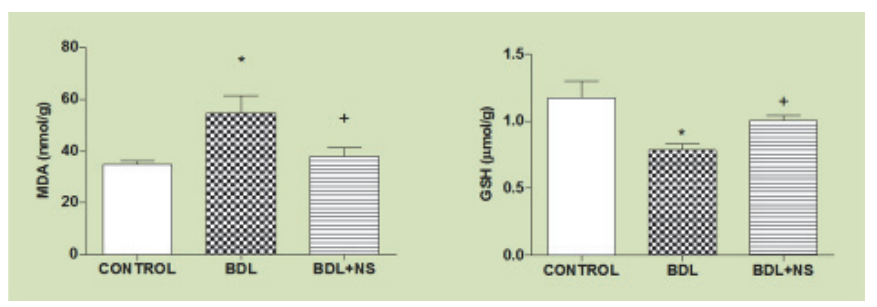

FIGURE1. a) Malondialdehyde (MDA) and b) Glutathione (GSH) levels in the brain tissues of control and saline- or Nigella sativa oil (NS)-treated bile duct ligated (BDL) groups ( $n=6$ per group). ${ }^{\star \star} p<0.05$ compared with control group. $+p$ $<0.05$, compared with saline-treated BDL group.

Myeloperoxidase activity, which is accepted as an indicator of neutrophil infiltration, was significantly higher in the brain tissue of the BDL group $(\mathrm{p}<0.01)$ than that of the control group $(p<0.05$, Fig 2$)$. On the other hand, NS treatment in the BDL group significantly decreased brain MPO level $(p<0.05)$ back 
to the levels of the control group. The activity of $\mathrm{Na}^{+}, \mathrm{K}^{+}$ATPase, indicating the functional transport capacity of the brain cells, was not found to be significantly different between the groups ( $p>0.05$, Figure 2$)$.

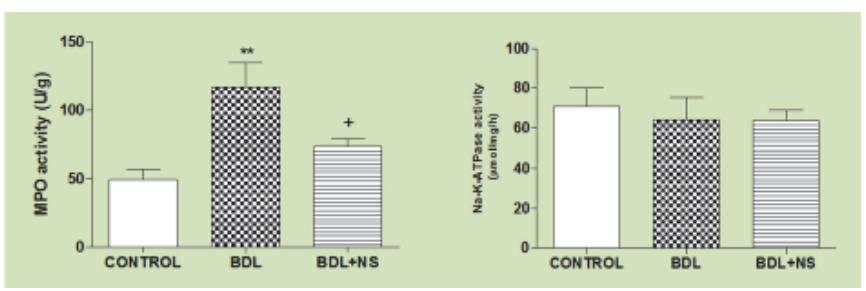

FIGURE 2. a) Myeloperoxidase (MPO)and b) Na-K-ATPase activity of the brain tissues in control and saline- or Nigella sativa oil (NS)-treated bile duct ligated (BDL) groups ( $n=6$ per group). ** $p<0.01$ compared with control group. $+p$ $<0.05$, compared with saline-treated BDL group.

Brain edema was not significantly different in any of the groups $(p>0.05)$. However, EB content of the brain significantly increased in the BDL group. NS treatment reduced the permeability but this reduction was not significant $(p>0.05$, Figure 3).

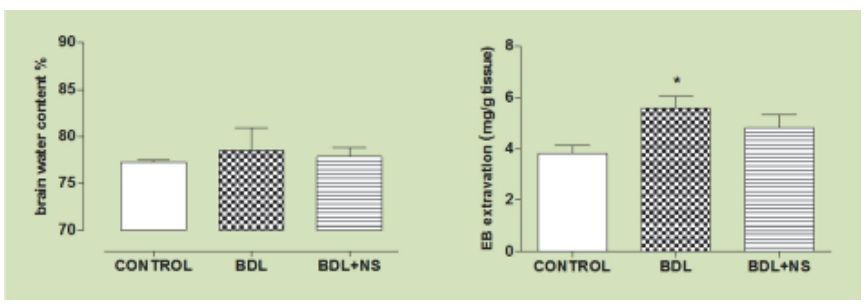

FIGURE 3. a) Evans blue (EB) extravasation and b) Water content of the brain tissues of control and saline or Nigella sativa oil (NS) -treated bile duct ligated (BDL) groups ( $n=6$ per group). ${ }^{\star} p<0.05$ compared with control group.

\section{DISCUSSION AND CONCLUSION}

Hepatic encephalopathy is caused by accumulation in the bloodstream of toxic substances that are normally removed by the liver. The diagnosis of hepatic encephalopathy requires the presence of impaired liver function and the exclusion of an alternative explanation for the symptoms. The mildest form of hepatic encephalopathy is difficult to detect clinically, but may be demonstrated by neurological examination. The first stage of hepatic encephalopathy is characterised by an inverted sleep-wake pattern. The second stage is marked by lethargy and personality changes. The third stage is marked by worsened confusion. The fourth stage is marked by a progression to coma (34).
This systemic inflammation can lead to vascular endothelium dysfunction. The breakdown of cerebral endothelial barrier contributes to life-threatening brain edema, thus worsening the respiratory function of the cells. Hypoxia and inflammation are linked to an alteration in the production of reactive oxygen and nitrogen species. Reactive oxygen species (ROS)induced oxidative stress plays a significant role in endothelial damage that leads to tissue injury. The initiation of lipid peroxidation, direct inhibition of mitochondrial respiratory chain enzymes, and other oxidative protein modifications contribute to the cytotoxic effect of $\operatorname{ROS}(35,36)$.

Glutathione is an important constituent of intracellular protective mechanisms against various noxious stimuli, including oxidative stress. Reduced glutathione, the main component of endogenous nonprotein sulfhydryl pool is known to be a major low molecular weight scavenger of free radicals in the cytoplasm. It has been proposed that antioxidants, which maintain the concentration of reduced GSH, may restore the cellular defense mechanisms, block lipid peroxidation, and thus protect against oxidative tissue damage (37). In the present study, we have found that biliary obstriction caused an increase in MDA levels, indirect indicator of increased lipid peroxidation, and MPO (an index for lekocyte infiltration) levels which was accompanied by a concomitant decrease in GSH levels, demonstrating the altered antioxidant status. NS oil treatment significantly reduced the rise in tissue MDA level and MPO activity and restored GSH content of the brain.

Generation of ROS contributes to endothelial and cellular dysfunction, resulting in increased BBB permeability and cerebral edema $(35,38)$. Besides the breakdown of BBB barrier, the failure of the $\mathrm{Na} / \mathrm{K}$ pumps, and the altered electrolyte balance of the cell, may also contribute to brain edema and pathological changes in the cellular function. In our study, we have also observed an increase in BBB and brain edema following jaundice. Supplementation with NS oil treatment did not significantly alter these changes. Moreover it failed to restore the decrease of $\mathrm{Na}^{+}, \mathrm{K}^{+}$-ATPase activity, which has an important role in edema formation $(23,38)$.

Our results suggest that NS oil treatment protects the brain from oxidative damage following bile duct ligation in rats. This effect possibly involves the inhibition of neutrophil infiltration and lipid peroxidation; thus, restoration of oxidant and antioxidant status in the tissue. Accordingly, supplementing cirrhotic patients with adjuvant therapy of NS oil may have some benefit against hepatic encephalopathy.

\section{DECLARATION OF INTEREST}

The study was supported by Marmara University Scientific Research Projects Commission, project no:SAG-D-050608-0132. The authors report no conflicts of interest.The authors alone are responsible for the content and writing of the paper. 
Nigella sativa yağının safra kanalı tıkanıklığı olan sıçanların beyin dokusundaki koruyucu etkisi

ÖZET: Oksidatif hasar tıkanma sarılığına bağı ensefalopatide önemli rol oynamaktadır. Çalışmamızın amacı Nigella sativa (NS, çörekotu) yağının safra kanalı tıkanıklığına bağlı oksidan beyin hasarında olası koruyucu etkisinin araştırılmasıdır.

Erkek Wistar albino sıçanların safra kanalları bağlandıktan sonra sıçanlara 28 gün süreyle intragastrik olarak NS yağı (1 mg/kg p.o.) ya da serum fizyolojik verilmiştir. Daha sonra Evans mavisi (EB) geçirgenliği yöntemiyle kan beyin bariyeri (KBB) değerlendirilmiştir. Ayrıca beyin dokuları çıkarılarak malondialdehid (MDA), glutatyon (GSH), myeloperoksidaz (MPO) ve $\mathrm{Na}^{+}, \mathrm{K}^{+}-\mathrm{ATPaz}$ aktivitesi ölçülmüştür.

Kronik safra kanalı tıkanıklığı KBB geçirgenliğinde anlamlı bir artışa neden olurken bu etki NS tedavisi ile azalmıştır. Diğer taraftan safra kanallarının bağlanmasıyla azalan beyindeki GSH düzeyi ve $\mathrm{Na}^{+}, \mathrm{K}^{+}-\mathrm{ATPaz}$ aktivitesi NS tedavisi ile neredeyse kontrol düzeylerine yükselmiştir. Beyin MDA düzeyi ve MPO aktivitesindeki artış da NS tedavisiyle önlenmiştir.

Bulgularımız NS tedavisinin safra tıkanıklığına bağlı beyin hasarına karşı koruyucu olduğunu göstermektedir. Dolayısıyla sirozlu hastalarda NS takviyesi hepatik ensefalopatiye karşı fayda sağlayabilir.

ANAHTAR SÖZCÜKLER: Nigella, çörek otu, safra kanalı, beyin, ödem

\section{REFERENCES}

1. Kullak-Ublick GA, Meier PJ. Mechanisms of cholestasis. Clin Liver Dis 2000; 4: 357-85

2. Montilla P, Cruz A, Padillo FJ, Tunez I, Gascon F, Munoz MC, Gomez M, Pera C. Melatonin versus vitamin E as protective treatment against oxidative stress after extrahepatic bile duct ligation in rats. J Pineal Res 2001; 31: 138-44.

3. Toklu HZ, Dumlu MU, Sehirli O, Ercan F, Gedik N, Gökmen V, Sener G. Pomegranate peel extract prevents liver fibrosis in biliary-obstructed rats. J Pharm Pharmacol 2007; 59: 1287-95.

4. Peres, W., Tunon, M.J., Collado, P.S., Herrmann, S., Marroni, N., Gonzalez-Gallego, J. The flavonoid quercetin ameliorates liver damage in rats with biliary obstruction. J Hepatol 2000; 33: 742-50.

5. Takaoka, M., Kubota, Y., Tsuji, K., Yamamoto, S., Ogura, M., Yanagitani, K., Shimatani, M., Shibatani, N., Inoue, K. Human neutrophil functions in obstructive jaundice. Hepatogastroenterology 2001; 48: 71-5.

6. Padillo, F.J., Muntane, J., Montero, J.L., Briceno, J., Mino, G., Solorzano, G., Sitges-Serra, A., Pera-Madrazo, C. Effect of internal biliary drainage on plasma levels of endotoxin, cytokines, and C-reactive protein in patients with obstructive jaundice. World J Surg 2002; 26: 1328-32.

7. Sener G, Sehirli AO, Toklu HZ, Yuksel M, Ercan F, Gedik N. Erdosteine treatment attenuates oxidative stress and fibrosis in experimental biliary obstruction. Pediatr Surg Int 2007; 23: 233-41.

8. Kountouras J, Billing $\mathrm{BH}$, Scheuer PJ. Prolonged bile duct obstruction: a new experimental model for cirrhosis in the rat. Br J Exp Pathol 1984; 65: 305-11.

9. Dunn CW, Horton JW,Megison SM, Vuitch MF. Contribution of portal systemic shunt to Kupffer cell dysfunction in obstructive jaundice. J Surg Res 1991; 50: 234-9.
10. Greve JW, Gouma DJ, Soeters PB, Buurman WA. Suppression of cellular immunity in obstructive jaundice is caused by endotoxins: a study with germ-free rats. Gastroenterology 1990; 98: 478-85

11. Jover R, Rodrigo $R$, Felipo $V$, et al. Brain edema and inflammatory activation in bile duct ligated rats and diet induced hyperammonemia: a model of hepatic encephalopathy in cirrhosis. Hepatology 2006; 43: 1257-66.

12. Butterworth RF, Norenberg $M D$, Felipo $V$, Ferenci $P$, Albrecht J, Blei AT; Members of the ISHEN Commission on Experimental Models of HE. Experimental models of hepatic encephalopathy: ISHEN guidelines. Liver Int 2009; 29: 783-8.

13. Randhawa $M$, Alghamdi $M$ (2011). Anticancer activity of Nigella sativa (black seed) - a review. Am J Chin Med 39: 1075-91.

14. Ali BH, Blunden $G$. Pharmacological and toxicological properties of Nigella sativa. Phytother Res 2003; 17: 299-305.

15. Butt MS, Sultan MT. Nigella sativa: Reduces the Risk of Various Maladies. Crit Rev Food Sci Nutr 2010; 50: 654-65.

16. El-Tahir KEDH, Bakeet DM. The black seed Nigella sativa linnaeus-. A Mine for multi-cures: A plea for urgent clinical evaluation of its volatile oil. JTU Med Sci 2006; 1: 1-19. Available from: http://jtaibahumedsc.net/issues/ volum1_issue1/1.pdf [Accessed: 06 Dec 2012]

17. Salem ML. Immunomodulatory and immunotherapeutic properties of the Nigella sativa L seed. Int imunopharmacol 2005; 5:1749-70.

18. Kaya MS, Kara M, Ozbek H. Seed of corek otu (Nigella sativa) effect human cell and immunity system CD3+, CD4+, CD8+ Cells and effect a number of total leucocytes. J. General Med 2003; 13: 109-12.

19. Demir H, Kanter M, Coskun O, Uz YH, Koc A, Yildiz A. Effect of black cumin (Nigella sativa) on heart rate, some hematological values, and pancreatic beta-cell damage in cadmium-treated rats. Biol Trace Elem Res 2006; 110: 151-62. 
20. Yildiz F, Coban S, Terzi A, Ates M, Aksoy N, Cakir H, Ocak AR, Bitiren M. Nigella sativa relieves the deleterious effects of ischemia reperfusion injury on liver. World J Gastroenterol 2008; 14: 5204-9.

21. Coban S, Yildiz F, Terzi A, Al B, Aksoy N, Bitiren M, Celik $H$. The effects of Nigella sativa on bile duct ligation induced-liver injury in rats. Cell Biochem Funct 2010; 28: 83-8.

22. Bayrak $O$, Bavbek $N$, Karatas OF, Bayrak R, Catal F, Cimentepe E, Akbas A, Yildirim E, Unal D, Akcay A. Nigella sativa protects against ischaemia/reperfusion injury in rat kidneys. Nephrol Dial Transplant 2008; 23:2206-12.

23. Erşahin $M$, Toklu HZ, Akakin $D$, Yuksel M, Yeğen BC, Sener $G$. The effects of Nigella sativa against oxidative injury in a rat model of subarachnoid hemorrhage. Acta Neurochir (Wien) 2011; 153:333-41.

24. $\mathrm{Al}$ Mofleh IA, Alhaider AA, Mossa JS, Al-Sohaibani MO, Al-Yahya MA, Rafatullah S, Shaik SA. Gastroprotective effect of an aqueous suspension of black cumin Nigella sativa on necrotizing agents-induced gastric injury in experimental animals. Saudi J Gastroenterol 2008; 14: 128-34.

25. Shimizu I, Ma YR, Mizobuchi $Y$, Liu F, Miura $T$, Nakai Y, Yasuda M, Shiba M, Horie T, Amagaya S, Kawada N, Hori H, Ito S. Effects of Sho-saiko-to, a Japanese herbal medicine, on hepatic fibrosis in rats. Hepatology 1999; 29: 149-60.

26. Martinek RG. A rapid ultraviolet spectrophotometric lactic dehydrogenase assay. Clin Chim Acta 1972; 40: 91-9.

27. Beuge JA. Aust SD. Microsomal lipid peroxidation. Methods Enzymol, 53: 302, 1978.

28. Beutler E. Glutathione in red blood cell metabolism. A manual of biochemical methods. New York: Grune\&Stratton, 1975; p.112.
29. Hillegass LM, Griswold DE, Brickson B, AlbrightsonWinslow C. Assessment of myeloperoxidase activity in whole rat kidney. J Pharmacol Methods 1990; 24: 285-95.

30. Reading HW, Isbir $\mathrm{T}$. The role of cation activated atpase in transmitter release from the rat iris. Q J Exp Physiol 1980; 65: 105-16.

31. Fiske $\mathrm{CH}$, Subbarow $\mathrm{Y}$. The colorimetric determination of phosphorus. J Biol Chem 1925; 66: 375-400.

32. Lowry OH, Rosenbrough NJ, Farr AL, Randall RJ. Protein measurements with the folin phenol reagent. J Biol Chem 1951; 193: 265-275.

33. Toklu HZ, Keyer Uysal M, Kabasakal L, Sirvanci S, Ercan F, Kaya M. The Effects of Riluzole on Neurological, Brain Biochemical, and Histological Changes in Early and Late Term of Sepsis in Rats. J Surg Res 2009; 152: 238-48.

34. Poh $Z$, Chang PE. A current review of the diagnostic and treatment strategies of hepatic encephalopathy. Int J Hepatol 2012; 2012:480309 Available from: http:/ / www. hindawi.com/journals/ijhep/2012/480309/ [Accessed: 06 Dec 2012]

35. De Vries HE, Kuiper J, De Boer AG, et al. The bloodbrain barrier in neuroinflammatory diseases. Pharmacol Rev 1997; 49:143-55.

36. Gilgun-Sherki Y, Melamed E, Offen D. Oxidative stress induced-neurodegenerative diseases: The need for antioxidants that penetrate the blood brain barrier. Neuropharmacology 2001; 40: 959-75.

37. Wu G, Fang YZ, Yang S, Lupton JR, Turner ND. Glutathione metabolism and its implications for health. J Nutr 2004; 134: 489-92.

38. Kempski O. Cerebral edema. Semin Nephrol 2001; 21: 303-7. 